\title{
ANALISIS PRODUKTIVITAS DAN EFISIENSI HUTAN TANAMAN INDUSTRI DALAM PRODUKSI KAYU BULAT DI INDONESIA
}

\author{
Ahmad Yani \\ Subdit Statistik Kehutanan- Badan Pusat Statistik \\ Email: ayani@bps.go.id
}

\begin{abstract}
Abstrak:
Produktivitas dan efisiensi merupakan masalah penting dalam sebuah kegiatan usaha, begitu juga dalam kegiatan industri kehutanan. Penelitian ini bertujuan untuk menganalisis tingkat produktivitas kegiatan hutan tanaman industri dalam memproduksi kayu bulat di Indonesia dalam kaitannya dengan dua faktor utama yaitu luas lahan budidaya dan tenaga kerja lapangan. Kajian ini dilakukan dengan pendekatan kuantitatif dengan metode analisis regresi linear berganda. Hasil analisis regresi linier berganda memperlihatkan adanya hubungan linier antara variabel luas lahan budidaya, variabel tenaga kerja lapangan dengan variable produksi. Temuan lain produktivitas hutan tanaman industri dalam menghasilkan kayu bulat semakin meningkat dan efisien. Variabel luas lahan budidaya merupakan faktor yang berpengaruh positif dan signifikan pada produksi kayu bulat, naiknya luas lahan akan menaikkan produksi kayu bulat. Tenaga kerja juga berpengaruh positif tetapi tidak signifikan pada produksi kayu bulat. Rasio produksi kayu bulat terhadap tenaga kerja menunjukkan efisiensi pemakaian tenaga kerja. Dengan tenaga kerja yang sedikit menghasilkan produksi yang lebih banyak.
\end{abstract}

Kata kunci: industri kehutanan, luas lahan budidaya kehutanan.

\begin{abstract}
:
Productivity and efficiency are important issues in a business activity, as well as in the activities of the forestry industry. This study aims to analyze the level of productivity of industrial plantations in producing logs in Indonesia in relation to two main factors, namely the area of cultivated land and field labor. This study was conducted with a quantitative approach with multiple linear regression analysis methods. The results of multiple linear regression analysis showed a linear relationship between the variable area of cultivated land, the variable of field labor with the variable of production. Another finding is the productivity of industrial plantations in producing logs and increasing and efficient. The variable area of cultivated land is a factor that has a positive and significant effect on log production, increasing the area of land will increase log production. Labor also has a positive but not significant effect on log production. The ratio of log production to labor shows the efficient use of labor. With less labor, more production
\end{abstract}

Keywords: field labor, forestry cultivation land area. 


\section{Pendahuluan}

Hutan merupakan sumber kehidupan bagi manusia yang sangat banyak manfaatnya (Muthmainnah, 2018). Dalam perkembangannya hutan telah dimanfaatkan untuk berbagai penggunaan, antara lain pemanfaatan hutan dalam bidang Hak Pengusahaan Hutan (Ginide dkk, 2013), Hak Pemungutan Hasil Hutan (Syaprillah, 2015), dan Hak Pengusahaan Hutan Tanaman Industri (HTI) (Yalid dan Dewi, 2017). Berdasarkan data dari Badan Pusat Statistik, produksi kayu bulat yang dihasilkan perusahaan HTI terus meningkat setiap tahunnya. Tahun 2017 produksinya mencapai lebih dari 36 juta meter kubik.

Tujuan dari penulisan untuk melihat bagaimana luas lahan yang digunakan untuk budidaya tanaman kehutanan dan jumlah tenaga kerja lapangan dalam meningkatkan produktivitas dan efisiensi terhadap produksi yang dihasilkan. Hasil kajian ini akan bermanfaat untuk perencanaan jumlah produksi di masa yang akan datang.

Sepanjang pengetahuan penulis. Studi tentang masalah ini sangat terbatas. Studi sebelumnya pernah dilakukan oleh fakhri dalam makalahnya " Makalah Statistik produksi kehutanan (academia.edu/18453687). Hasil studi tersebut menunjukk terdapat hubungan linier antara jumlah pekerja tetap dan produktivitas kayu bulat serta terdapat pengaruh yang signifikan antara variabel jumlah pekerja tetap terhadap produktivitas kayu bulat.

\section{Metodologi.}

Metode yang digunakan dalam penelitian ini adalah analisis deskriptif dan regresi linier berganda sederhana. Regresi linier berganda sederhanaa. Analisis deskriptif digunakan untuk mendapatkan gambaran umum terkait variable produksi, tenaga kerja lapangan dan luas lahan untuk budidaya. Regresi linier berganda digunakan untuk mrlihat melikat pengaruh dari variable-variabel bebas terhadap varabel terikat. Variable bebas terdiri dari luas lahan untuk budidaya di notasikan $\left(\mathrm{X}_{1}\right)$ dan jumlah pekerja lapangan $\left(\mathrm{X}_{2}\right)$. Variable terikatnya produksi kayu bulat (Y). Model regresi linear berganda dilukiskan dengan persamaan sebagai berikut:

$\mathrm{Y}=\alpha+\beta 1 \mathrm{X} 2+\beta 2 \mathrm{X} 2+\beta \mathrm{n} \mathrm{Xn}+\mathrm{e}$

Keterangan:

$\mathrm{Y}=$ Variabel terikat atau response.

$\mathrm{X}=$ Variabel bebas atau predictor.

$\alpha=$ Konstanta.

$\beta=$ Slope atau Koefisien estimate.

Sumber data pada penelitian ini menggunakan data sekunder dari publikasi Satistik Perusahaan Pembudaya Tanaman kehutanan tahun 2002 sampai tahun 2017, yang dihasilkan oleh subdit statistik kehutanan - Badan Pusat Statistik dari pendataan pada perusahaan HTI di seluruh Indonesia. Variable yang digunakan produksi kayu bulat, luas lahan untuk budidaya dan tenaga kerja lapangan. Hipotesa pada penelitin ini, adanya pengaruh dari luas budidaya dan tenaga kerja terhadap produksi yang dihasilkan perusahaan HTI. Kerangka pikir dari studi ini 


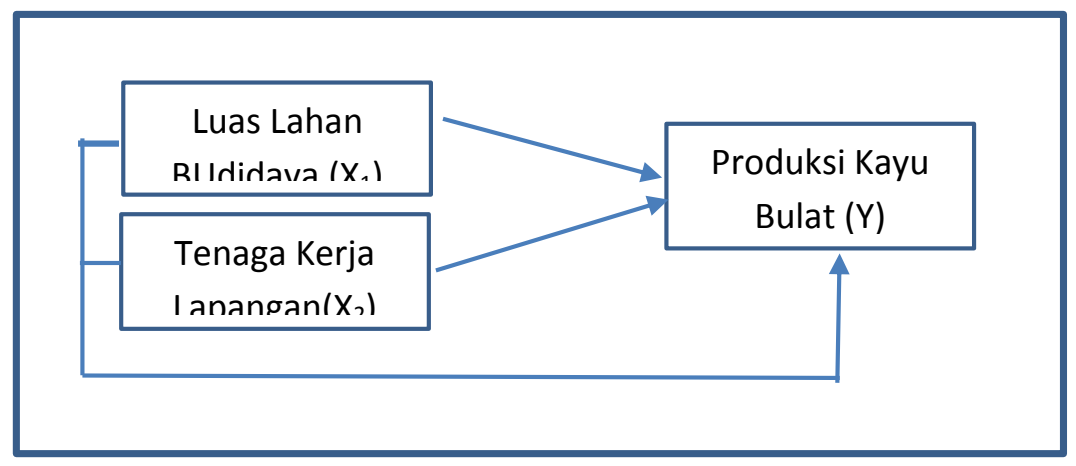

\section{Hasil dan Pembahasan}

\section{Analisis Deskriptif}

Kayu bulat merupakan salah satu produk dari perusahaan HTI. Kayu bulat dihasilkan dari penebangan pohon di kawasan Hutan yang menjadi haknya perusahaan HTI.

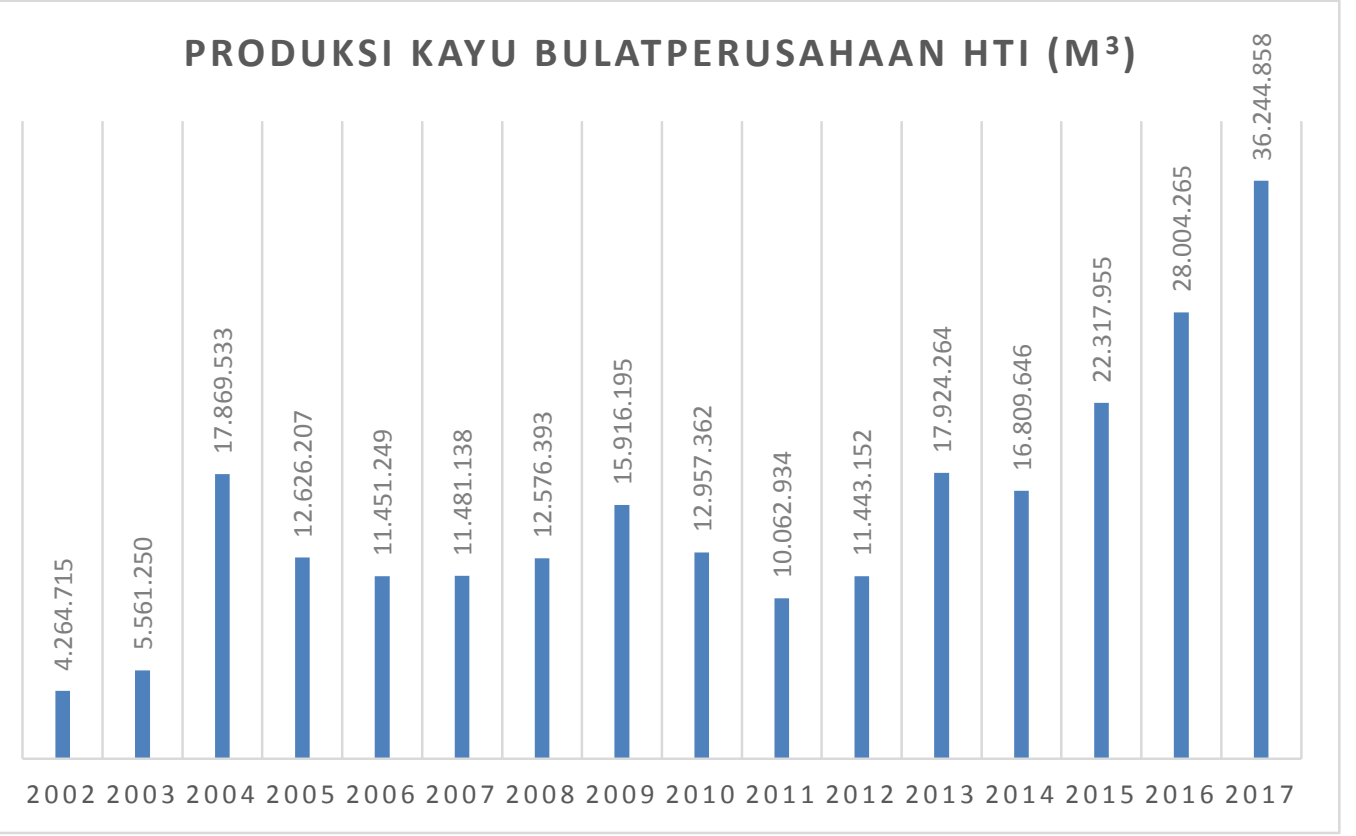

Gambar 1. Produksi kayu bulat perusahaan HTI tahun 2002 - 2017

Sumber: BPS

Produksi sejak 2002 produksi kayu bulat terus meningkat jumlahnya. Tahun 2002 produksinya hanya sekitas 4 juta meter kubin lebih. Sekarang Pada 2017 mencapai kurang lebih 36,24 juta meter kubik. Dibanding produksi tahun 2016 meningkat sebesar 29 persen lebih . Produksi kayu bulat mengalami lonjakan yang signifikan mulai dari tahun 2014, yaitu dari 16,8 juta meter kubik menjadi 36 juta lebih meter kubik, naik 100 persen lebih. (115,62 \%). Kenaikan produksi kayu bulat. Seiring dengan naiknya jumlah luas lahan yang dikuasai perusahaan HTI untuk membudidayakan tanaman.

Trend Luas Lahan untuk Budidaya tanaman kehutanan mulai tahun 2002 hingga tahun 2017 terus meningkat. Tahun 2002 luasnya hanya sekitar 2,8 juta 
hektar, tahu 2017 mencapai 6,5 juta hektar. Luasan tahun 2017 mengalami penurunan kurang dari 1 persen dari tahun 2016. Luas Lahan untuk budidaya terluas terjadi pada tahun 2012 .

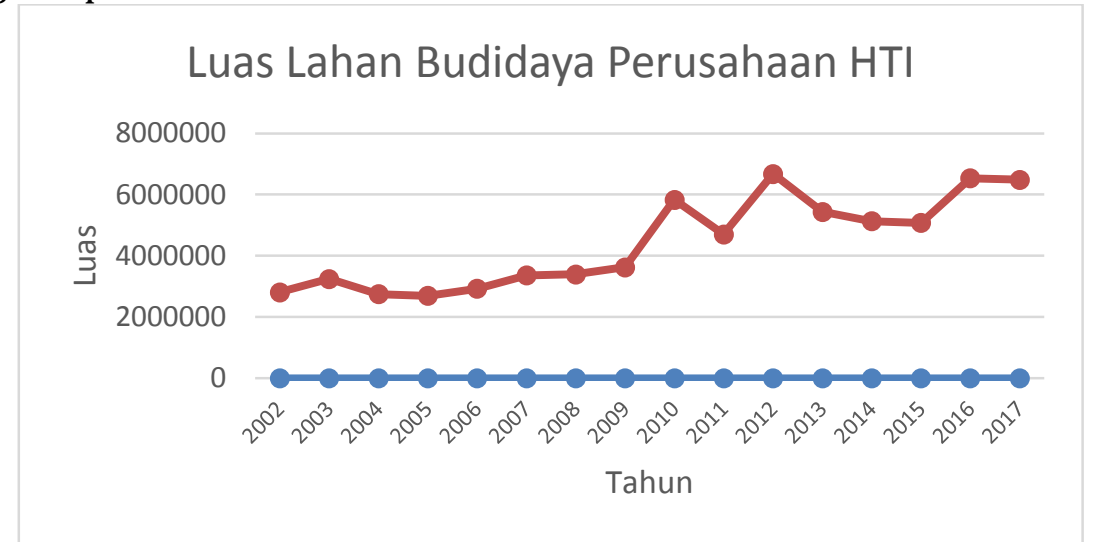

Gambar 2. Luas lahan Budidaya Pada Perusahaan HTI tahun 2002 - 2017 Sumber: BPS

Tahun 2012 luas lahan untuk budidaya seluas 6,68 juta hektar tetapi produksinya jauh lebih rendah dari tahun 2017 yang luasnya 6,65 juta hektar. Tahun 2017 perusahaan HTI produktivitasnya lebih tinggi. Tahun 2012 produktivasnya hanya 1,17 meter kubik per hektar, ditahun 2017 produktivitasnya mencapai 5,59 meter kubik per hektar.

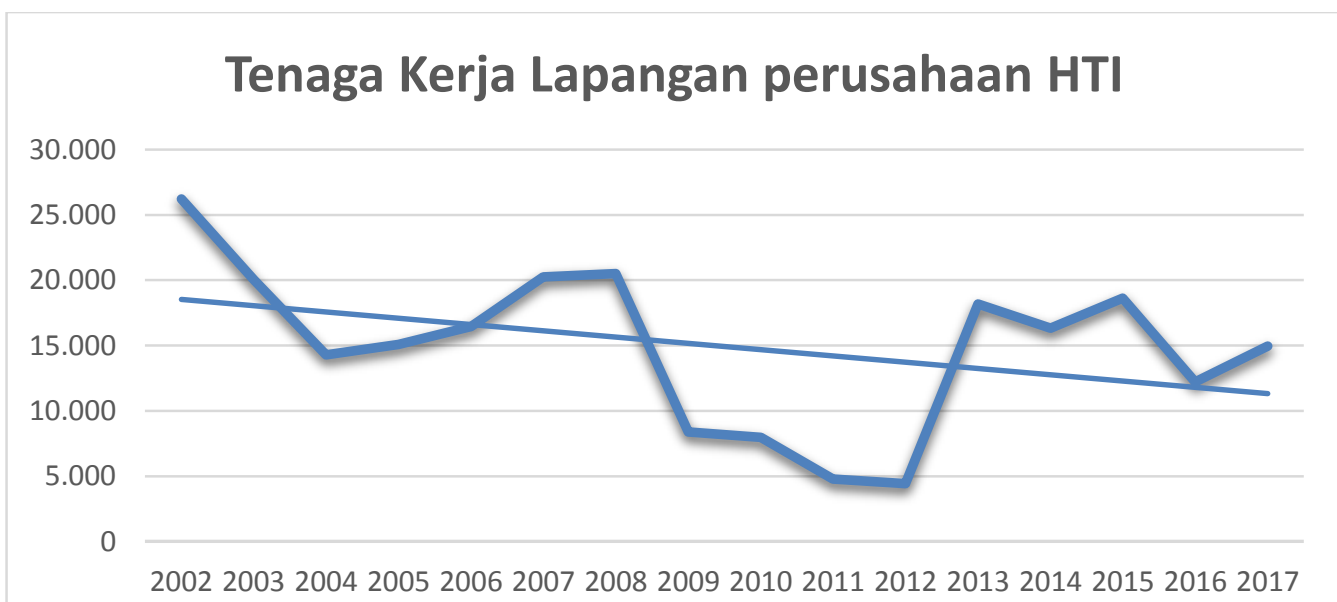

Gambar 3. Jumlah Tenaga kerja lapangan Pada Perusahaan HTI tahun 2002 - 2017 Sumber: BPS

Tenaga kerja lapangan merupakan unit yang cukup penting di perusahaan HTI. Mereka melakukan perawatan tanaman dan penebangan pohon (produksi). Tenaga kerja manusia dibutuhkan dalam proses produksi untuk melakukan berbagai pekerjaan berupa pengolahan tanah, penanaman, pemeliharaan tanaman, panen, pasca panen, dan pemasaran hasil (Marianne Reynelda Mamondol.2017). dan menurut Sukirno (2001) tenaga kerja merupakan bagian dari faktor-faktor produksi.

Sejak tahun 2002 semakin berkurang penggunaannya. Tahun 2002 tenaga kerja lapangan yang digunakan diatas 25 ribu orang. tahun 2009 hingga tahun 2012 jumlah tenaga kerja yang digunakan rata-rata dibawah 15 ribu orang. penggunaan 
terendah tahun 2008, hanya dibawah 5 ribu tenaga kerja lapangan. Jumlah tenaga kerja lapangan tahun 2017 mencapai 14955 orang, naik 22,24 persen. dibanding tahun 2016. Penurunan jumlah tenaga kerja lapangan diduga karena semakinnya berkembangnya teknologi dalam bidang kehutanan anatara lain dengan penggunaan chainsaw. Kegiatan penebangan pohon di hutan rakyat dilakukan menggunakan alat tebang chainsaw dengan kisaran produktivitas penebangan $4,880 \mathrm{~m}^{3} /$ jam-8,578 m³ $/$ jam (Sukadaryati et al ,2018). Berarti dalam kurun 1 tahun berkisar $6344 \mathrm{~m}^{3}$ sampai $11.151 \mathrm{~m}^{3}$ ( 1 hari 5 jam kerja ).

\section{Series Tenaga Kerja dan Produksi Kayu Bulat pada}

\section{Perusahaan HTI}

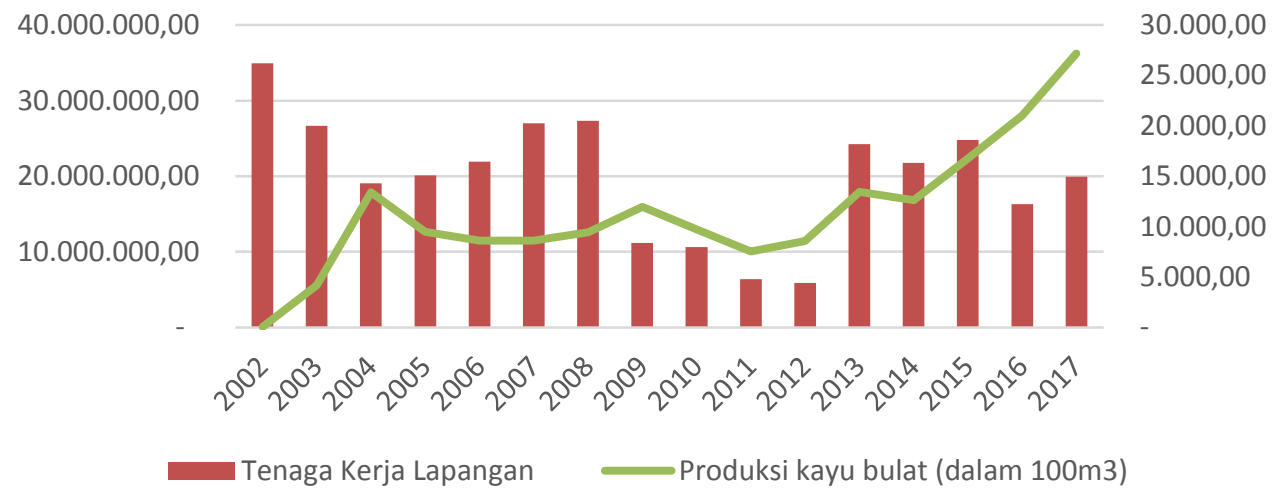

Gambar 4. Tenaga Kerja dan Produksi Kayu Bulat pada Perusahaan HTI tahun 2002 $-2017$

Sumber: BPS

Tahun 2002 tenaga kerja yang banyak tetapi produksi kayu bulat yang dihasilkan sedikit, tetapi Tahun 2017 dengan tenaga kerja yang lebih sedikit menghasilkan produksi yang cukup tinggi dengan kata lain lebih efisien.

\section{Analisis Regresi Linier berganda}

Pengujian ada tidaknya pengaruh dari luas lahan untuk budidaya dan jumlah tenaga kerja lapangan dengan analisis regresi linier berganda, dimulai dengan menguji asumsi klasik (Ghozali, 2006) yaitu multikolinier, heteroskedastisitas, kenormalan dan autokorelasi.

- tidak terdapat masalah multikolinearitas, Winarno (2015) menjelaskan mengenai multikolinearitas yaitu adanya hubungan linier antara variabel independen (bebas).

- tidak terjadi masalah heteroskedastisitas, untuk mengetahui apakah dalam suatu model regresi terdapat persamaan atau perbedaan varians dari residual satu pengamatan ke pengamatan yang lain.

- Kenormalan, Winarno (2015) menyatakan bahwa salah satu asumsi dalam analisis statistika adalah data berdistribusi normal

- Autokorelasi, Winarno (2015) menyatakan bahwa autokorelasi adalah hubungan antara residual atau observasi dengan residual observasi lainnya pada data yang diuji .

Hasil uji Asumsi yang di uji dari data-data tersebut semuanya terpenuhi, tidak melanggar asumsi. 
- Hasil penghitungan regresi data produksi, luas lahan budidaya dan tenaga kerja lapangan dengan software SPSS didapat :

Tabel 1. Nilai Koefisien Regresi

\begin{tabular}{|c|l|r|}
\hline No & \multicolumn{1}{|c|}{ Variabel } & \multicolumn{1}{|c|}{ Nilai Koefisien Regresi } \\
\hline 1 & Konstanta & -5338999.943 \\
\hline 2 & Luas Budidaya $\left(\mathrm{X}_{1}\right)$ & 3.812 \\
\hline 3 & Tenaga Kerja Lapangan $\left(\mathrm{X}_{2}\right)$ & 265.696 \\
\hline 4 & R Square & 0.388 \\
\hline
\end{tabular}

Nilai Koefisien Determinasi yang diperoleh dari pengolahan data SPSS adalah 0,388 artinya variable luas lahan budidaya dan tenaga kerja lapangan secara simultan berpengaruh terhadap produksi sebesar 38,8 \%. Sedangkan sisanya dipengaruhi oleh variabel lain diluar persamaan regresi ini atau variabel yang tidak diteliti.

Dari table 1. data yang diolah dengan SPSS menghasilkan model persamaan regresi $Y=-5338999,943+3,812 \mathrm{X}_{1}+256,696 \mathrm{X}_{2}$. Model tersebut dapat diinterpretasikan bahwa, setiap 1 hektar lahan akan mempengaruhi produksi sebesar 3,812 meter kubik. setiap 1 orang pekerja lepas akan meningkatkan produksi kayu bulat sebesar 256,67 meter kubik. Penggunaan tenaga kerja lapangan cukup efieisen.

Tabel 2. dibawah. Ratio produksi terhadap tenaga kerja semakin meningkat. Tahun 2002 rasionya sekitar 162 lebih

Tabel 2. Ratio Produksi Terhadap Lahan budidaya dan tenaga kerja lapanagan

\begin{tabular}{|r|r|r|r|}
\hline Tahun & $\begin{array}{c}\text { Rasio Produksi } \\
\text { Terhadap Luas } \\
\text { Lahan Budidaya }\end{array}$ & $\begin{array}{c}\text { Rasio Luas Lahan } \\
\text { Budidaya Terhadap } \\
\text { Tenaga Kerja } \\
\text { lapangan }\end{array}$ & $\begin{array}{c}\text { Rasio Produksi } \\
\text { Terhadap Tenaga Kerja } \\
\text { Lapangan }\end{array}$ \\
\hline 2002 & 1,52 & 107,34 & 162,73 \\
\hline 2003 & 1,71 & 162,16 & 277,83 \\
\hline 2004 & 6,50 & 192,66 & 1251,63 \\
\hline 2005 & 4,68 & 178,70 & 837,00 \\
\hline 2006 & 3,92 & 177,67 & 695,62 \\
\hline 2007 & 3,41 & 166,02 & 566,72 \\
\hline 2008 & 3,70 & 165,79 & 1897,72 \\
\hline 2009 & 4,39 & 432,66 & 1626,38 \\
\hline 2010 & 2,22 & 732,36 & 2103,46 \\
\hline 2011 & 2,14 & 983,79 & 2583,10 \\
\hline 2012 & 1,71 & 1507,31 & 986,75 \\
\hline 2013 & 3,30 & 299,32 & 1030,00 \\
\hline 2014 & 3,28 & 314,41 & 1199,25 \\
\hline 2015 & 4,40 & 272,69 & \\
\hline
\end{tabular}




\begin{tabular}{|l|r|r|r|}
2016 & 4,29 & 534,97 & 2292,99 \\
\hline 2017 & 5,59 & 433,93 & 2423,59 \\
\hline
\end{tabular}

Data hasil olahan, sumber BPS

Dan pada tahun 2017 rationya 2.423 lebih berarti 1 orang pekerja lapangan menghasilkan dua ribu meter kubik lebih kayu log setiap tahunnya.

\subsection{Uji Statistik-F}

Tujuan dari Uji F-statistik ini adalah untuk mengetahui pengaruh semua variabel independen secara bersama-sama terhadap variabel dependen. Statistik uji F mengikuti distribusi $\mathrm{F}$ dengan derajat bebas sebanyak (k-1) untuk numerator dan (n-k) untuk denumerator, dimana $\mathrm{k}$ menunjukkan banyaknya parameter termasuk intersep/konstanta, sedangkan $\mathrm{n}$ adalah banyaknya observasi (Widarjono, 2007 dalam Pratowo, 2012).

Tabel 2. Dibawah merupakan hasil penghitungan data dengan menggunakan SPSS.

Tabel 3. Hasil Uji Anova

\begin{tabular}{|l|r|r|r|r|c|}
\hline \multicolumn{1}{|c|}{ Model } & Sum of Squares & df & Mean Square & F & Sig. \\
\hline 1 Regression & 377337363143478.25 & 2 & 188668681571739.12 & 4.115 & $.041^{b}$ \\
\hline Residual & 596063010907792.60 & 13 & 45851000839060.97 & & \\
\hline Total & 973400374051270.90 & 15 & & & \\
\hline \\
a. Dependent Variable: PRODUKSI \\
b. Predictors: (Constant), NAKER, LUAS
\end{tabular}

Berdasarkan tabel output ANOVA. Nilai Sig dalam uji F adalah $=0,041$. Nilai tesebut $<0.05$, maka dapat disimpulkan bahwa Luas lahan budidaya dan tenaga kerja lapangan secara simultan (bersama-sama) berpengaruh terhadap produksi kayu bulat atau signifikan.

\subsection{Uji Statistik - t}

Untuk melihat masing-masing variable bebas apakah berpengaruh terhadap variable terikat. Maka dalam analisi regresi linier berganda dilakukan Uji t-Statistik. Table 2 merupakan hasil pengolahan data dengan SPSS,

Tabel 2. Hasil Uji T

\begin{tabular}{|c|c|c|c|c|c|c|}
\hline \multirow{2}{*}{\multicolumn{2}{|c|}{ Model }} & \multicolumn{2}{|c|}{ Unstandardized Coefficients } & \multirow{2}{*}{$\begin{array}{c}\text { Standardized } \\
\text { Coefficients }\end{array}$} & \multirow[b]{2}{*}{ t } & \multirow[b]{2}{*}{ Sig. } \\
\hline & & $\mathrm{B}$ & Std. Error & & & \\
\hline \multirow[t]{3}{*}{1} & (Constant) & -5338999.943 & 9695510.769 & & -.551 & .591 \\
\hline & LUAS $\left(\mathrm{X}_{1}\right)$ & 3.812 & 1.368 & .698 & 2.786 & .015 \\
\hline & NAKER $\left(\mathrm{X}_{2}\right)$ & 265.696 & 332.471 & .200 & .799 & .439 \\
\hline
\end{tabular}


Variabel Luas memiliki nilai t hitung sebesar 2,786 dan nilai signifikansi sebesar 0,015 pada tingkat signifikansi 0,05. Dapat di simpulkan bahwa 0,015 >0,05 ,maka hipotesis yang berbunyi “ Luas Lahan Budidaya berpengaruh positif terhadap produksi kayu bulat pada perusahaan HTI " diterima.

Variabel Tenaga kerja Lapangan memiliki nilai t hitung sebesar 0,799 dan nilai signifikansi sebesar 0,439 pada tingkat signifikansi 0,05. Dapat di simpulkan bahwa 0,439 > 0,05 ,maka hipotesis yang berbunyi “ Tenaga kerja lapangan berpengaruh positif terhadap produksi kayu bulat pada perusahaan HTI " ditolak dengan kata lain tidak berpengaruh secara signifikan terhadap produksi.

\section{Kesimpulan dan saran}

\section{Kesimpulan}

Berdasarkan hasil dan pembahasan dapat disimpulkan bahwa :

a) kayu bulat yang dihasilkan oleh perusahaan HTI dari tahun 2002 hingga tahun 2017 mengalami peningkatan yang sangat tajam.

b) Berdasarkan analisis regresi, diperoleh model persamaan regresi $\quad Y=$ 5338 999,943 + 3,812 X $1+256,696 \mathrm{X}_{2}+$ e. Dari nilai R2 (koefisien Determinasi) hasil uji sebesar 0,388 dapat disimpulkan bahwa faktor luas lahan budidaya dan tenaga kerja lapangan secara simultan berpengaruh terhadap produksi sebesar 38,8 \%. Sedangkan sisanya dipengaruhi oleh variabel lain diluar persamaan regresi ini atau variabel yang tidak diteliti. Berdasarkan uji $\mathrm{F}$ juga menunjukkan kedua faktor tersebut secara bersama-sama berpengaruh secara signifikan terhadap produksi kayu bulat.

c) Secara parsial, uji statistik dengan tingkat kepercayaan 5 persen menunjukkan bahwa :

- Faktor luas lahan budidaya berpengaruh secara nyata dan positif terhadap jumlah produksi kayu bulat.

- Faktor tenaga kerja lapangan berpengaruh positif akan tetapi tidak signifikan terhadap jumlah produksi kayu bulat

d) Temuan dari hasil analisis regresi di atas menunjukkan bahwa produktivitas dan efisiensi produksi kayu bulat mengalami peningkatan. Dari sisi tenaga kerja lapangan, dimana 1 orang akan meningkatkan lebih 256 meter kubik kayu bulat.

\section{Saran.}

Untuk melihat faktor-faktor yang mempengaruhi produksi kayu bulat pada penelitian selanjutnya, perlu manambahkan variabel lain seperti pupuk, pestisida dan bibit yang mempengaruhi besaran jumlah produksi. Sehingga dapat meningkatkan produktivitas kayu bulat pada perusahaan HTI.

\section{Daftar Pustaka}

Badan Pusat Statistik. (2018). Statistik Perusahaan Pembudidaya Tanaman Kehutanan Tahun 2002 - 2017. Jakarta: BPS.

Fakhri. (t.thn.). (DOC) Makalah Statistik Produksi Kehutanan. Diakses pada tanggal 8 $\begin{array}{lllll}\text { Mei } & 2019 & \text { pukul } & 11.00 & \text { WIB }\end{array}$ 
https://www.academia.edu/18453687/Makalah Statistik Produksi Kehutan an.

Mamondol. (2017). EFISIENSI PENGGUNAAN FAKTOR PRODUKSI TENAGA KERJA DAN MODAL PADA USAHATANI KEDELAI DI KELURAHAN PAMONA KECAMATAN PAMONA PUSELEMBA KABUPATEN POSO. Jurnal ENVIRA Volume 2 Nomor 2 Desember 2017

Muthmainnah dan Tanur, M. (2018). Nilai Manfaat Ekonomi Hutan Kota Universitas Hasanuddin Makassar. Jurnal Hutan dan Masyarakat, 10(2).

Sukadaryati et al. Pemanenan Kayu Hutan Rakyat (Studi Kasus di Ciamis, Jawa Barat) .Jurnal Ilmu Kehutanan 12 (2018).

Sukirno, S. (2001). Pengantar Teori Ekonomi.Jakarta: Raja Grafindo Persada.

Syaprillah, A. (2015). Nilai Manfaat Ekonomi Hutan Kota Universitas Hasanuddin Makassar. Jurnal Rechts Vinding, 4(2).

Winarno, W. W. (2015). Analisis Ekonometrika dan Statistika dengan EViews. Edisi ke-4. Yogyakarta: UPP STIM YKPN

Yalid, dan Dewi, S. (2017),. Kewajiban Investor Bidang Usaha Tanaman Industri. Jurnal Hukum Novelty, 8(1). 